\title{
O FILME ESTÔMAGO: Comida, diversão e arte
}

\author{
Denise Azevedo Duarte Guimarães ${ }^{1}$
}

\begin{abstract}
Resumo: Este artigo toma o premiado filme Estômago (2007) como seu objeto de estudo, para investigar como a arte culinária é apresentada, focalizando suas formas simbólicas e implicações sociais ligadas à identidade. Tentamos compreender os modos como produtos da indústria cultural podem associar dimensões artísticas aos conceitos de entretenimento e de espectatorialidade cinematográfica. Enfatizamos também a proposta peculiar do filme, que, ao recusar representações usuais da violência e da miséria, distingue-se no contexto do cinema brasileiro contemporâneo.
\end{abstract}

Palavras-chave: Arte culinária. Conflitos identitários. ; Cinema brasileiro.

\begin{abstract}
Abstract:
This article takes the awarded film Estômago (2007) as its analytic object, in order to investigate how culinary art is presented, on focusing its simbolic forms and social implications facing identity conflicts. We try to understand the ways cultural industry products can associate artistic dimensions to the concepts of entertainment and cinematic spectatorship. We also emphasize the film's singular proposal, which, by refusing recurrent representations of violence and misery, outstands itself within the context of contemporary Brazilian cinema.
\end{abstract}

Key-words: Culinary art; Identity conflicts; Brazilian cinema.

“A gente não quer só comida, a gente quer comida, diversão e arte. A gente não quer só comida, a gente quer bebida, diversão, balé. A gente não quer só comer, a gente quer prazer pra aliviar a dor. A gente não quer só dinheiro, a gente quer dinheiro e felicidade."

( “Comida"- Titãs) ${ }^{2}$

\section{A compensação estética da violência}

Narrativas fílmicas podem ser entendidas como processos de mediação cultural, uma vez que os filmes refletem a visão e o sentido conferido às coisas e às ações pelos membros de uma sociedade específica, além de contemplarem suas construções

\footnotetext{
${ }^{1}$ Doutora em Estudos Literários pela UFPR. Docente do PPGCCOM/UTP - denise.guimaraes@utp.br

2 “Comida”, de Arnaldo Antunes, Marcelo Fromer e Sérgio Brito, gravado pelos Titãs no CD Acústico, pela Epiphone, 1997
} 
simbólicas e questões identitárias. Pelo fato de ligar-se a diversificados gêneros narrativos e tendências estéticas, a linguagem sensorialmente rica e estilisticamente múltipla do cinema acolhe um amplo leque de propostas diversificadas.

$\mathrm{Na}$ cinematografia brasileira, no entanto, ainda são raros os filmes que conseguem escapar das explicações dos teóricos da indústria cultural sobre o declínio do indivíduo; o que resulta em imagens consensuais e estereotipadas do cidadão displaced e marginalizado - visto como fruto de equivocados processos de socialização, nas grandes cidades. Ao adotar o viés de fuga desses padrões repetitivos, o filme Estômago (2007)[i] - objeto empírico deste estudo - muito embora explore temáticas e cenários recorrentes no cinema brasileiro, consegue estatuir-se pela diferença, optando por uma a parábola bem humorada e amoral, que consegue apontar para as entranhas de mazelas sociais, no país da "fome zero".

Acredito que a busca insana do poder, por parte do protagonista, ligar-se-ia a uma concepção da atividade artística como parte integrante da identidade, mesmo que em ambientes carentes e degradados. Essa é a razão da escolha dos versos da canção “Comida”, da banda Titãs (CD Acústico, 1997), como epígrafe deste artigo.

Como ocorre na letra da música, a cidade e seus notívagos frequentadores expõem suas carências e conflitos, de uma forma limítrofe, porém velada: além do bem e do mal. Todos estão em busca da completude, de algo que lhes confira o status da cidadania, de algo além da simples alimentação necessária à sobrevivência. São indivíduos que desejam algo mais para se tornarem plenos: “A gente quer inteiro e não pela metade”, diz o verso final da música.

Em seu primeiro longa-metragem, o diretor paranaense Marcos Jorge opta pela paradoxal inserção do universo da gastronomia no chamado "submundo" - o que interpreto como uma metáfora da força da arte em ambientes improváveis. É nesse sentido que a premissa básica de meu artigo advém da consideração de que as sequiências do filme revelam uma compensação estética, de tal modo que a violência impactante e o tom grotesco ficam reservados para o desfecho.

\section{O filme como objeto de consumo: premiações e bilheterias}

O cinema é tido como um meio de comunicação majoritariamente ligado ao consumo e suas produções têm alimentado uma indústria cada vez mais voltada para os 
sucessos de bilheteria. Muito embora o público do cinema brasileiro tenha caído nos últimos cinco anos e o conceito de indústria cinematográfica seja ainda utópico entre nós, as premiações internacionais têm contemplado, com certa frequência, nossos cineastas e atores - o que não deixa de ser motivador.

Por outro lado, como sabido é que o dialogo entre a crítica especializada e o público está longe de ser harmonioso, raros são os casos de filmes nacionais premiados que, ao ousarem romper com aquelas estruturas narrativas estereotipadas e folclóricas, conseguem efetivamente fazer sucesso.

Dentre as produções brasileiras recentes que têm conseguido atrair espectadores para as salas de cinema e, posteriormente, para as locadoras, destaca-se o premiado filme de Marcos Jorge, cujo site oficial informava (em 19/06/ 2008) que, em nove de dez semanas em exibição, Estômago fora a maior bilheteria do cinema nacional no período e já era a quarta bilheteria do cinema brasileiro em 2008. Informava-se também que o filme estivera, por dez semanas consecutivas, na lista dos melhores filmes da Revista Veja São Paulo.

Dando início a uma trajetória de sucesso no exterior, no segundo semestre de 2008, Estômago tem destaque em uma série de festivais: o Latinbeat 2008, promovido pelo Film Society of Lincoln Center, em Nova Iorque; o AFI Latin American Film Festival, em Los Angeles; ou o Antalya Film Festival, na Turquia; tendo também sido escolhido para abrir a Mostra “Occhio sul Mondo”, do Festival de Cinema de Roma..

Seis meses depois, outra notícia, dentre as inúmeras que comentam a distribuição e a significativa recepção internacional do filme, enfatiza que o lançamento espanhol, bastante "aguardado depois de ter vencido os prêmios principais da prestigiosa Semana Internacional de Cinema de Valladolid”, é três vezes maior do que o realizado no Brasil: “ ...o filme faz parte do portfólio da Alta Films, uma das maiores distribuidoras da Espanha, que o apresenta no circuito comercial com aproximadamente 50 cópias...” (site oficial do filme)

Destaco ainda o fato de a produção realizar movimentos, ainda raros ou mesmo inéditos no Brasil, em direção à espectatorialidade, viabilizando uma série de eventos e produtos concebidos a partir do filme, com vistas ao mercado. Dentre eles, merecem ser citados: a participação na noite de abertura do Fantastic Fest 2008 (Texas), com direito a jantar inspirado no menu do filme, após a sessão; e, também, o lançamento do Roteiro 
de Estômago durante a Mostra Internacional de Cinema de São Paulo/2008, edição da Imprensa Oficial de São Paulo. O livro apresenta diversos extras, entre os quais o "Livro de Receitas do Filme".

Além de D. Flor e Seus Dois Maridos, de Bruno Barreto (1976), o longametragem paranaense parece ser um dos raros, entre nós, a tratar, da gastronomia como uma manifestação artística observável e capaz de proporcionar uma experiência estética, sem perder de vista a ampliação de seus espaços no mercado.

No mundo todo, embora não cheguem a constituir recordes de bilheteria, inúmeras são as produções cinematográficas que, já pelo título, anunciam o tema da culinária e têm relativo sucesso de público, sendo que algumas delas conseguiram consagrar-se como obras-primas da cinematografia mundial. ${ }^{3}$ Tais filmes despertam meu interesse, pela forma como exploram os aspectos e valores ligados à interculturalidade da representação social da comensalidade, seja na linha dos chamados filmes de arte, seja como produtos mais voltados para o consumo massivo. O que parece haver em comum entre todos estes filmes, produzidos em diferentes latitudes e longitudes, é que cada narrativa vai, pouco a pouco, destacando o motivo central da trama: a gastronomia e seus desdobramentos, em suas associações com as mais inusitadas opções humanas.

No decorrer das eras e nas mais diferentes localizações geográficas, a escolha dos ingredientes e as maneiras de combiná-los definem sabores e aparências, que se tornam referenciais culinários de uma dada cultura. Tais elementos têm possibilitado o bem sucedido tratamento do tema gastronômico via discurso cinematográfico.

Na America Latina, dentre alguns filmes que abordam a culinária ${ }^{4}$, um exemplo marcante é o mexicano Como água para chocolate (1992), que mescla fatos históricos e realismo fantástico. Dirigido por Alfonso Arau e baseado no livro de Laura Esquivel, o filme tem como cenário uma fazenda mexicana. Utilizando-se de receitas e segredos, que aprendeu com a velha cozinheira, bem como do seu prazer em manipular os ingredientes, a jovem protagonista vai modificando as situações e operando seus “milagres”, enquanto dedica-se ao preparo da típica culinária regional de seu país, com

\footnotetext{
${ }^{3}$ Os mais consagrados são: A Festa de Babette (1988) de Gabriel Axel; A Comilança (1973), de Marco Ferri; O cozinheiro, o ladrão, sua mulher e e o amante (1989) de Peter Greenaway.

${ }^{4}$ Alguns títulos que merecem destaque: Herencia. Direção: Paula Hernández, 2001, Argentina; O filho da noiva (2001), de Juan José Campanella, Argentina; A Última Ceia. Direção de Tomás Gutierrez Alea, 1976, Cuba.
} 
seu poder encantatório. Toda a diegese é envolvida numa atmosfera entre a magia e a técnica: magia produzida pela arte de transformar coisas comuns em algo extraordinário; técnica inerente à natureza do ato de cozinhar, ou seja, preparar e submeter, com conhecimento, os alimentos à ação do fogo, para, de certa forma, transubstanciá-los.

Assim como o filme de Arau, Estômago revela-se repleto de expressivos detalhes e sutilezas cênicas. Uma das opções da direção é propiciar o raro prazer de observar como os personagens podem desfrutar a comida, não só como alimento para o corpo, mas também esteticamente; o que se traduz em imagens que causam impacto no espectador, porque oscilam entre o sublime e o patético.

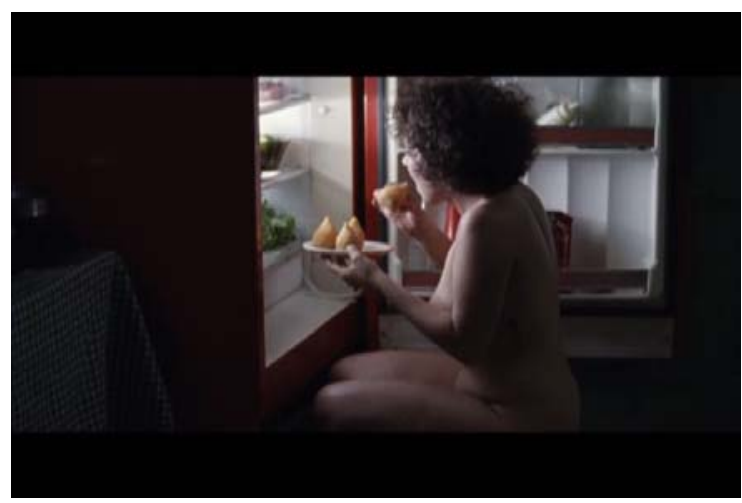

Fig.1 - Entre o sublime e o patético

Mesmo que em condições e espaços os mais adversos, como ilustra a cena acima, o jogo de formas e luzes confirma a força do impulso erótico que se alia ao lúdico, revelando-se em cada sequência fílmica, em cada tomada que mostra a preparação dos pratos, através de suas cores, texturas, combinações e sugestões sinestésicas. A câmera vai das apetitosas e eróticas coxinhas do boteco, feitas pelo cozinheiro de primeira viagem, ao processo de escolha dos ingredientes, no Mercado Municipal, para a elaboração do cardápio pretensamente requintado do pequeno restaurante.

$\mathrm{Na}$ fragmentada diegese, os cortes entre as cenas do passado e aquelas da prisão são, geralmente, feitos a partir de sequências que envolvem a alimentação, com ênfase em estímulos sensoriais. É nessas primorosas imagens da cozinha, reveladoras do vigor dos alimentos em sua exuberância de cores e formas, que o protagonista cumpre ritos iniciáticos, tanto no preparo das refeições, quanto na estreita relação entre comida e sexo, algumas vezes pendendo para a luxúria. 
Muitas das imagens gastronômicas tomam a tela toda, configurando um timing semelhante ao do cinema europeu, onde o essencial não é a dimensão mecânica do tempo, mas sim sua duração. Trata-se de um método dramático de veiculação do equivalente psicológico do presente, através da memória do narrador, o que poderia ser explicado em termos da durée bergsoniana, ou seja, de um "passado sempre-presente" que se movimenta em um fluxo contínuo e que altera a percepção da realidade, entre o que foi e o que poderia ter sido.

\section{Estômago e os modelos estético-representacionais do cinema brasileiro}

Diante do exposto, creio ser relevante destacar que os dois espaços centrais do filme, o centro histórico e o presídio, embora opostos, interpenetram-se e são habitados por personagens similares, ensejando representações urbanas que se repetem ao longo das últimas cinco décadas de cinema brasileiro. ${ }^{5}$

Com o objetivo de contextualizar meu objeto empírico e de fundamentar minha argumentação, refiro-me aos dois grandes modelos estético-representacionais do cinema nacional da segunda metade do século passado: o Cinema Novo e o Cinema da Retomada. Ambos, na sequência histórica, vêm influenciando a produção de filmes que apresentam os excluídos e marginalizados, como visões da sujeira, da feiura e da agressividade; elementos esses que passaram a marcar nosso imaginário cultural sobre como é o Brasil.

Minhas reflexões encaminham-se para afirmar que o filme de Marcos Jorge desenvolve-se na contramão da "estética da fome" glauberiana, que tem marcado o cinema nacional com suas incisivas propostas de arte revolucionária, desde 1960, e que tem mantido seus reflexos, muitas vezes reconfigurados, em produções cinematográficas mais recentes.

Sabe-se que o Cinema Novo é definido pela idéia da fome não apenas como tema, mas, principalmente, como um princípio estruturante básico da forma de fazer filmes - algo extremamente importante, tendo em vista o contexto político brasileiro de

\footnotetext{
${ }^{5}$ Cumpre ressaltar que o cinema brasileiro não se restringe a esta tradição representacional, pois a filmografia nacional integra filmes históricos, românticos, dramas, comédias, entre outros gêneros que não necessariamente dialogam com a miséria e a violência.
} 
então. Trata-se daquele modo de dizer que produz sentidos ligados ao subdesenvolvimento, ao tematizar uma fome que se instala nas estratégias discursivas e nas próprias formas de expressão. O manifesto intitulado Estétyka da Fome, na grafia preferida por seu autor Glauber Rocha ${ }^{6}$; é o texto fundamental para a compreensão do projeto cultural dos cineastas brasileiros da época. Ao considerar que a fome está enraizada na própria incivilização, Glauber afirma que somente os cineastas com propostas semelhantes às suas são capazes de compreender esta espécie de "estranho surrealismo tropical”, como entendido pelo europeu, ou esta "vergonha nacional”, para o brasileiro que não come, mas tem vergonha de dizer.

Sabemos nós - que fizemos filmes feios e tristes, estes filmes gritados e desesperados onde nem sempre a razão falou mais alto - que a fome não será curada pelos planejamentos de gabinete (...). Assim, somente uma cultura da fome, mirando suas próprias estruturas, pode superar-se qualitativamente: e a mais nobre manifestação cultural da fome é a violência. (ROCHA, 1965. on-line: www. estetica-dafome-manifesto-de-glauber).

O cineasta explica que a violência de um faminto, mostrada pelo Cinema Novo, não é primitiva, mas sim revolucionária. Numa das frases mais incisivas e conhecidas do manifesto, o autor afirma que "nossa cultura nasce da fome" (op.cit). Assim é que o texto de Glauber consegue ir além da denúncia das misérias latino-americanas, pela ênfase dada à arte revolucionária.

O diferencial do filme Estômago é que, de imediato, percebe-se que tanto o caráter documental quanto o de crítica social ostentiva são cuidadosamente evitados, bem como qualquer preocupação com o politicamente correto - o que eu definiria como a paradoxal tematização da arte culinária em tempos de cestas básicas. É nesse sentido que entendo o filme como uma celebração poética do tema da comensalidade, em tudo o que ele pode trazer de beleza trágica, conseguindo ser clamoroso, sem explicitar qualquer discurso panfletário.

Por outro lado, o filme rompe também com a estética da violência do chamado Cinema da Retomada, na última década do século XX, bem como daqueles rotulados

\footnotetext{
${ }^{6}$ A Estética da Fome, de Glauber Rocha, foi originalmente apresentada em 1965, durante as discussões da Resenha do Cinema Latino-Americano de Gênova., cujo tema era "O paternalismo do europeu em relação ao Terceiro Mundo" O artigo/manifesto foi publicado pela primeira na Revista Civilização Brasileira (número 3, julho de 1965), com novos e vários apontamentos, para deixar mais claras suas idéias. Fonte: http://memoriasdosubdesenvolvimento.blogspot.com/2007/06/estetica-da-fome-manifestode-glauber.html. (acesso em 20 de nov.2008)
} 
como do Cinema Pós-retomada (a partir de 2001). São produções que atualizam e ressignificam representações da miséria e da violência, com novas estratégias discursivas e cujas narrativas fílmicas tornaram-se ainda mais agressivas, como ocorre em Carandiru, Cidade de Deus, Amarelo Manga, Tropa de Elite, O cheiro do ralo, entre outros. Em que pesem as qualidades desses filmes, considero discutível considerálos como "herdeiros" do Cinema Novo (1960-70), que se propunha a retratar a realidade brasileira, cheia de miséria e injustiças sociais, sob a influência do neo-realismo europeu, porém com fins ideológicos específicos.

O que se oberva majoritariamente nas telas de hoje, é que, por força do crescimento urbano desordenado resultante da forte migração, o foco da violência trocou o campo pela cidade grande. Seu espaço agora é o carcerário, o das favelas, das gangues, dos sem-teto, entre outros cenários similares, nos quais crônicas policiais ou a "guerra” contra os traficantes são ostensivamente reiterados, em filmes que, muitas vezes, em nome dos apelos comerciais, generalizam, banalizam ou espetacularizam fatos violentos em si. São elementos que suscitam desconforto, em oposição aos filmes ditos comerciais - considerados “pasteurizados” porque ostentam belos cenários e personagens de classes privilegiadas.

Não se pode tratar do assunto sem lembrar a polêmica causada pelo artigo "Da Estética à Cosmética da Fome”, publicado no Jornal do Brasil, julho de 2001, ${ }^{7}$ no qual a pesquisadora Ivana Bentes retoma o manifesto de Glauber Rocha. A autora entende a retomada dos temas do Cinema Novo (a miséria e a violência), por parte do cinema brasileiro contemporâneo, como uma forma de espetacularização. Destarte, seriam os filmes atuais destituídos do sentido afirmativo e transformador presente naquelas obras que buscavam reverter, num impulso criador mítico e onírico, a pobreza e a miséria latino-americanas, com ênfase nos fenômenos ligados à fome. Na filmografia recente, segundo Bentes, a denúncia social e política, bem como a ética e estética, cederiam lugar ao puro entretenimento, com o abuso de formas folclorizadas, paternalistas, conformistas e piegas.

\footnotetext{
${ }^{7}$ BENTES, Ivana. Da estética à cosmética da fome. http://bravonline.abril.com.br/ (Acesso - 3 de dez.2008).
} 
Nesse contexto, considero que o filme Estômago afirma-se duplamente pela diferença: não só ao desconstruir chichês da violência urbana, mas também por absterse das representações folclóricas ou glamourizadas do Brasil.

A estética e a ética do alimento

Neste filme que trata da comensalidade em termos estéticos e eróticos, mas vai além, ao revelar algumas das mais inusitadas opções humanas, a gastronomia é marcada pela ética e pela estética do alimento, com seus desdobramentos sociais e morais.

A enunciação fílmica de Estômago gira em torno da possibilidade de exercício do poder, que pode ser conquistado de várias e insólitas maneiras. No entanto, sua ênfase recai nos pequenos e miúdos atos cotidianos, a partir do momento em que o protagonista faz descobertas sobre sua habilidade na arte de cozinhar e dela faz uso, como possibilidade de forjar uma identidade e de conquistar a cidadania plena.

A diegese está centrada na metamorfose de (João Miguel) Raimundo Nonato um migrante nordestino pobre, sem cultura e sem profissão definida, que tenta conquistar um espaço potencialmente hostil, no sul do país. Sua história, aparentemente, não é de rejeição, nem de exclusão, mas sim a de um homem tranquilo e humilde, que tem oportunidade de inclusão social graças a seus dons culinários. É primorosa a construção de Nonato como um ser ambíguo por excelência, enigmático, aparentemente frágil e ingênuo. Afinal, o cozinheiro é apresentado sem a afirmação de uma identidade pré-existente: dele nada se sabe, antes de sua chegada a Curitiba.

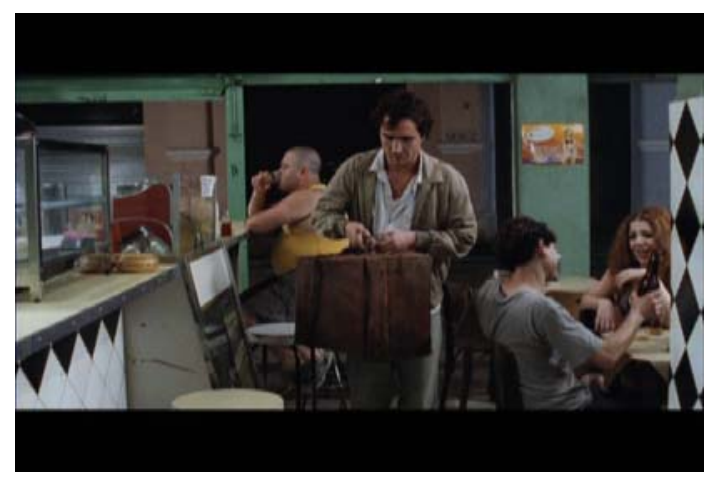

Fig. 2. Chegada ao boteco

O protagonista, “exilado” na capital sulina, passa por um processo psíquico de construção identitária, que pode ser vinculado ao drama do pertencimento. É nesse sentido que considero pertinente relacionar a fragmentada prática discursiva que conduz a diegese fílmica ao contexto das teorias pós-colonialistas. Segundo o pensamento de Homi Bhabha, um sujeito sempre está em relação diferencial com o Outro e é marcado 
pela duplicidade, o que lhe confere um certo "ar de incerteza", de um corpo sob a ameaça constante do ser "desmembrado", como afirma o autor:

Assim, em termos psíquicos, a identidade nunca existe $a$-priori, nunca é um produto acabado; sempre é apenas o processo problemático de acesso a uma imagem de totalidade.[...] O acesso à imagem da identidade só é possível através da negação de um senso de originalidade ou plenitude, através do princípio do deslocamento e diferenciação (ausência/presença; representação/repetição) que sempre a torna uma realidade ambígua. A imagem é, ao mesmo tempo, uma substituição metafórica, uma ilusão de presença e, por isso mesmo uma metonímia, signo da ausência e perda da presença. (BHABHA, 1986, p. 63)

Acredito que o protagonista de Estômago aproxima-se deste “sujeito” dual porque, sendo ambíguo e dissimulado, ele descobre que o poder pode ser alcançado através do estômago. Então, passa a usar seus dotes culinários para fascinar e seduzir; e assim o faz com a prostituta glutona - (Fabíula Nascimento) Iria - e também com o patrão -(Carlo Briani) Giovanni - , dono do pequeno restaurante e terceiro elemento de um triângulo amoroso habilmente escamoteado pela narrativa em primeira pessoa.

Em uma das primeiras cenas dentro da prisão, o protagonista diz para si mesmo: "Raimundo Nonato, cozinheiro? Não dá mais! Depois da merda que eu fiz, tem que ser um nome do cangaço mesmo. (...) Nonato Canivete. Isso é nome de bandido!” O monólogo seria redundante, pois o espectador já sabe que algum crime o levou à prisão; no entanto, a informação central, sobre de que crime se trata, não é fornecida no transcorrer dos episódios narrados, sendo revelada apenas no clímax da narrativa.

Assinalo que os dados mais relevantes da fala de Nonato dizem respeito à necessidade de assumir uma nova identidade. A expressão “nome do cangaço” traz à tona, pela única vez no filme, seu espaço de origem - o nordeste brasileiro, onde, por sinal, o termo cangaceiro tem conotações ambíguas, ligadas a herois sertanejos. Logo, cangaceiro e bandido não são exatamente sinônimos. Além disso, a alcunha “Canivete”, escolhida por Nonato, remete ao objeto usado à guisa de arma branca por pequenos marginais urbanos, cuja conotação torna-se irônica e vem implicitar o rebaixamento da autoimagem do protagonista.

Isso não o torna inseguro, pelo contrário, ajuda-o a continuar com seu perfil dissimulado e lhe possibilita atingir o ambicionado poder. Relegado, nos primeiros dias, ao chão do canto imundo da cela, o cozinheiro rapidamente conquista, graças a seus 
dotes culinários, o beliche de baixo, depois o do meio e então cobiça o beliche de cima. Ao observar o bandido chefão da cela - (Babu Santana) o Bujiú - comendo com o maior prazer a refeição “melhorada” por ele, Nonato filosofa: “Como o ser humano amolece fácil com a boa comida!”

Na sequência final, o cozinheiro se esmera na organização do grotesco banquete dentro do presídio, enfatizando que estar à mesa exige utensílios, mobiliário, espaço arquitetônico ou cênico, além de todo um conjunto de formalidades e protocolos. Detalhes das minúcias do preparo dos pratos, dos legumes coloridos sendo fatiados, das carnes sendo cortadas, dos ruídos dos utensílios e das sugestões olfativas, contrapõemse a imagens primitivas da “realidade” carcerária. Efetiva-se, assim, a metaforização gastronômica de todo o cinismo que preside as relações sociais, metonimicamente representadas naquele microcosmo prisional.

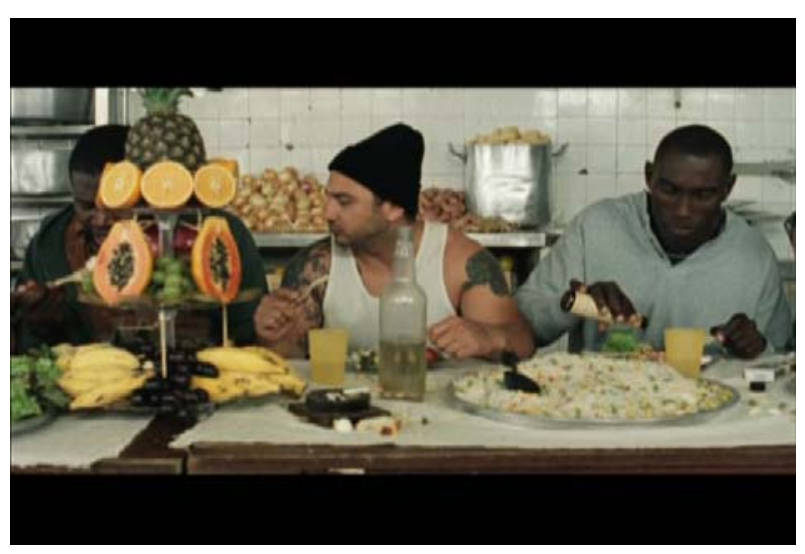

Fig.3 - O banquete na prisão

Nesse momento, a luxúria anterior cede lugar à gula, expondo as dualidades humanas entre a animalidade e o refinamento alimentar. A ocasião mostra-se perfeita para que Raimundo Nonato exerça sua perversidade, oriunda da ambição desmedida, sob a forma de uma vingança que não é meramente pessoal, mas sim emblemática, pois expressa os traumas decorrentes de sua condição social e de uma vida de subserviência. A sequência final configura-se, portanto, como um anticlímax bastante adequado à tensão criada pelos jogos temporais da montagem, nesta instigante narrativa fílmica emoldurada pela voz em off do narrador-protagonista.

\section{Tensão e conflitos existenciais no espaço-tempo}


Com apenas algumas cenas em São Paulo, as filmagens de Estômago aconteceram na capital do Paraná, tendo como principais locações o presídio do Ahú e o centro histórico de Curitiba. Como assinalei anteriormente, tanto o presídio quanto os demais cenários do filme são bastante diversos do celebrado Carandiru ou de filmes similares.

Destaque-se a opção pela representação da cidade de forma aparentemente neutra, com a completa ausência dos “cartões postais”. Curitiba em si não exerce um papel tão especial na vida desses personagens, que não pudesse ser vivido em outros locais - o que, acredito, justificaria a ausência de cenas diurnas no filme.

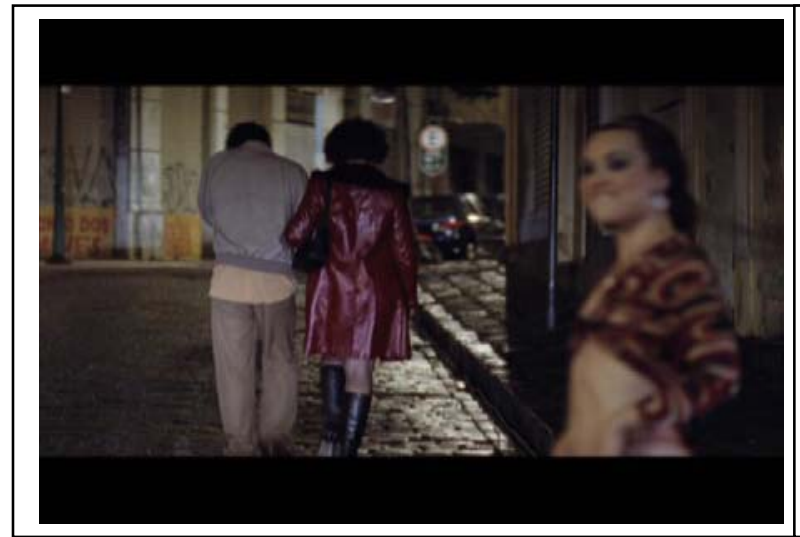

Fig. 4 -O casal no, de costas, no centro de Curitiba

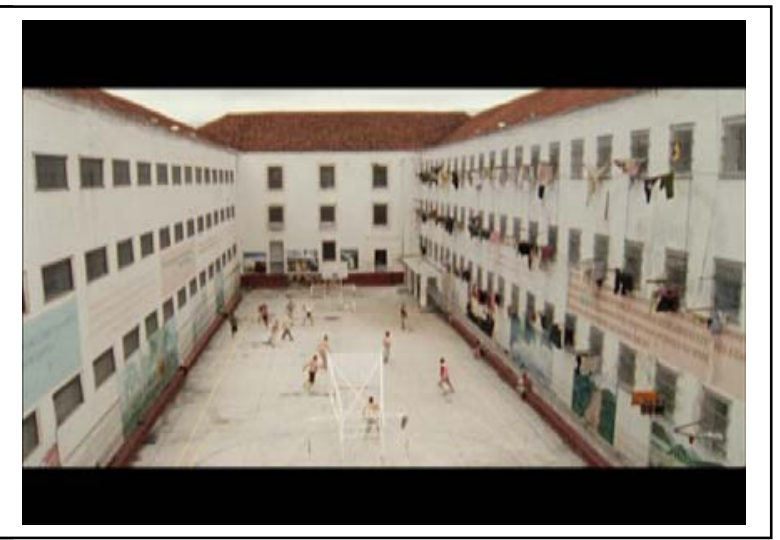

Fig. 5 - O presídio do Ahú

O presídio do Ahú, hoje desativado, é o espaço a partir do qual se faz ouvir a voz do narrador-protagonista, através de um frenético contraponto entre cenas da prisão e momentos relembrados, após sua chegada a Curitiba. O filme contrapõe duas coordenadas espaciais e temporais: de um lado, o passado, no espaço aberto e libertário do submundo de uma capital do sul do país, com seus ambientes do baixo meretrício, boites e botecos; do outro, o momento presente da enunciação, no confinamento do universo carcerário.

A narrativa ganha força nas imagens noturnas das ruas do centro histórico, com pouca iluminação e com as paredes grafitadas, onde perambulam frequentadores marginalizados; entretanto, não parece haver perigo à vista e tudo funciona dentro de uma ética própria, sem conflitos entre eles, sem a presença da polícia e sem apelos a uma visão caricata da prostituição. Não há excessos, justamente porque o cerne da 
narrativa liga-se a conflitos indentitários do ambíguo protagonista, sendo que a incógnita sobre a razão de ele estar na prisão só é desvendada no final.

Logo após chegar à rodoviária da cidade, Raimundo Nonato consegue seu primeiro emprego, num boteco decadente e sujo, porém central. Ali, logo descobre um inusitado talento para a culinária, preparando deliciosas coxinhas, o que transforma o local e atrai rapidamente nova freguesia. No entanto, é um pequeno restaurante italiano que se torna o centro nevrálgico e deflagrador dos conflitos básicos da narrativa, ao intermediar os dois espaços principais do filme: o centro histórico e a prisão.

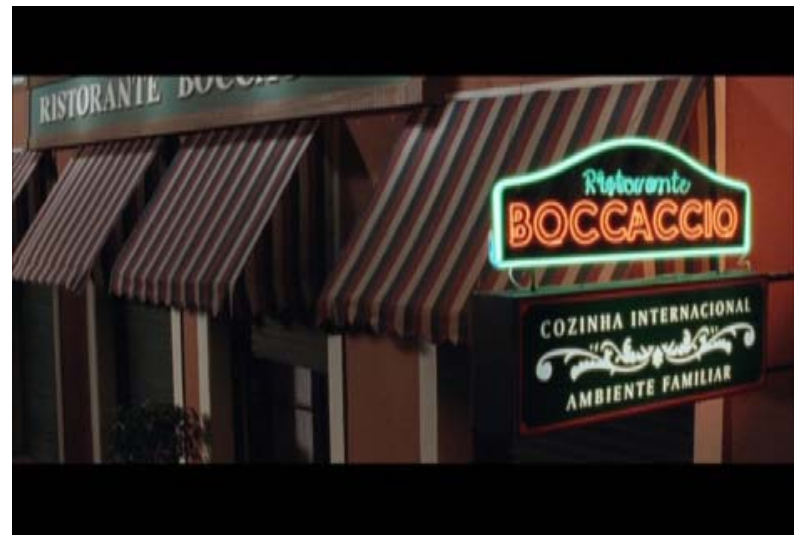

Fig. 6. O restaurante

A fachada do restaurante demonstra a consolidação de um modelo alternativo e híbrido de cidade brasileira, aqui corporificado na capital paranaense. No entanto, ao enfatizar os espaços fechados, o cineasta consegue representar modos de vida, usos e costumes urbanos ageográficos, bem como relações interpessoais aparentemente tranquilas, porém repletas de conflitos implicitados no decorrer da diegese fílmica.

Creio ser relevante observar o modo como o filme de Marcos Jorge efetiva uma sutil e pertinente reflexão social, através de um olhar que parte do presídio, para oscilar entre a chamada "boca do lixo" no centro da cidade e o simulacro do luxo no limitado restaurante. Além dos locais citados, outro ambiente fechado importante no filme é o Mercado Municipal, apresentado ao protagonista pelo novo patrão, Giovanni, que o inicia nos detalhes da profissão de cozinheiro, a partir da seleção dos melhores ingredientes. 


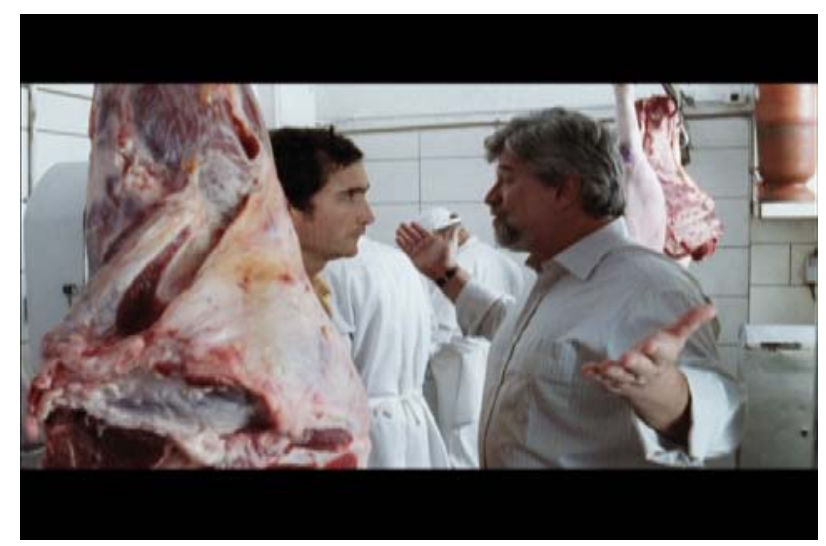

Fig. 7 - No açougue

Na primeira visita ao mercado, apesar dos apelos visuais das frutas, legumes e produtos expostos, o protagonista mantém sua atitude lacônica e contida, em flagrante contraste com a gesticulação do prolixo restauranteur, como se vê na emblemática sequência do açougue. Com muita carne e muito sangue à mostra, a sequência está repleta de imagens indiciais, que apontam para um sangrento desfecho, mas que é continuamente escamoteado pelas estratégias narrativas.

Na segunda visita ao mercado, Nonato é acompanhado por Iria, alegre, falante e querendo provar tudo o que vê, enquanto o cozinheiro mal pronuncia alguns vocábulos e esboça raros sorrisos contidos. A sorridente e gulosa prostituta sente fome o tempo todo, o que costuma expressar verbalmente: "Desde que nasci estou com fome e ela nunca mais parou.” Obviamente o sentido literal do vocábulo traz também conotações relevantes para a compreensão da personalidade de Iria e do tipo de envolvimento que ela mantém com Nonato.

A harmonia entre eles só é rompida na cena do strip-tease da moça, na boite. Trata-se de uma performance bastante sensual, mas dentro dos limites, em se tratando do ambiente; porém, o ingênuo nordestino tem um ataque de ciúmes e acaba levando uma surra dos seguranças. Deixando-se levar pela ilusão do amor, Nonato chega a pedir Iria em casamento e até convida os padrinhos. Só então, descobre que seu patrão tem um relacionamento amoroso com a moça; fato que, diante de sua ingenuidade, provoca um ciúme desmedido e atinge dimensões trágicas exacerbadas, somente mostradas no desfecho.

Com seu erotismo latente e não tão escancarado como em outros filmes brasileiros, a trama de Estômago desenvolve-se na subversão intencional do espaço e do 
tempo, em nome da exacerbação dos sentidos, da gula, da luxúria e dos prazeres da mesa ou na cama. É o que pode ser observado numa das cenas mais picantes do filme:

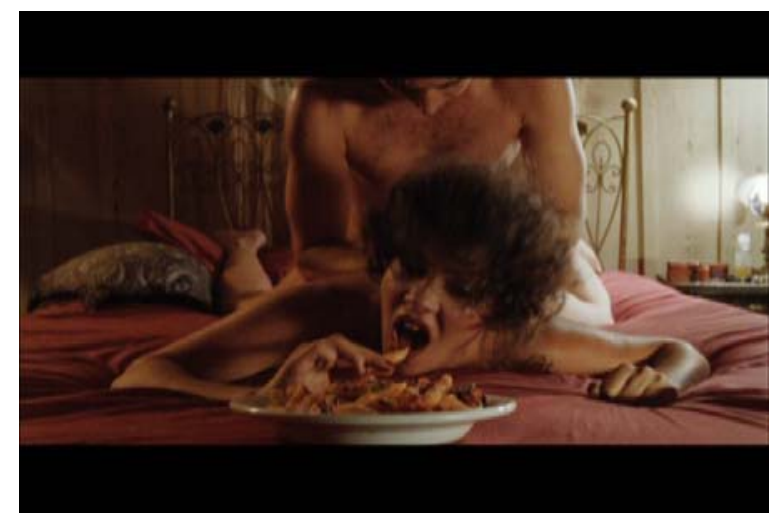

Fig. 8 - O erotismo grotesco

Embora intensa, a cena não explicita detalhes anatômicos ou imagens gratuitas. Retomando a letra da música citada na introdução deste artigo, o tom da sequência filmada, entre o irônico e o bizarro, mostraria que “A gente não quer só comer, a gente quer comer e quer fazer amor”. A fome da protagonista, mais do que as cenas revelam, expressaria carências e dramas mais profundos.

Eu diria que o filme analisado associa-se à concepção freudiana de que o trajeto que vai da boca ao estômago estaria nas origens da vida e do gozo sexual, ficando claros os poderes do alimento e de quem o fornece ou prepara. Entretanto, embora sua trama traga outros elementos ligados ao "prato" erótico, o modo visceral com que as cenas são filmadas, com tomadas e travellings pouco convencionais, faz do filme um exercício expressivo e revelador sobre a capacidade do cinema de oferecer imagens capazes de ultrapassar a história que ajudam a narrar.

Focalizando as armadilhas semânticas e sensoriais, percebidas no desenvolvimento do filme, enfatizo que os prazeres dos sabores ligam-se a tentações pecaminosas implícitas. Assim é que um jogo cênico repleto de imagens sinestésicas trata a luxúria como elemento deflagrador do trágico - que é levado ao clímax na sequência do assasinato dos amantes e no sádico requinte do preparo cuidadoso do pedaço de carne, a ser colocado na nádega da amada morta. As formas como as cenas eróticas vão sendo construídas contribuem para o entendimento do universo em que a protagonista vive e de sua ausência de culpa, provocando a piedade catártica perante seu trágico fim. 


\section{5. À guisa de conclusão}

Este artigo procurou demonstrar que o filme Estômago despreza os estereótipos midiáticos sobre os espaços urbanos menos nobres e seus habitantes, ou seja, aqueles das notícias dos telejornais e frequentes no cinema nacional. Longe de trazer a concepção da experiência cotidiana como sujeita à crescente violência e fortemente colorida pela "fome", no sentido mais amplo do termo, o filme analisado opta por modulações temáticas sutilmente poéticas. Todavia, está implícito na obra o universo canibal e antropofágico, que toma a culinária como metáfora para tratar das relações de poder e das contradições sociais.

Em consonância com a tradição européia de cinema, a narrativa fílmica distancia-se daquelas imagens que, ao se repetirem, criam um pacto com o público e tornam-se um senso comum sobre a nossa identidade, como uma nação marcada pela miséria e suas consequências. Acredito que, a promover o diálogo entre a percepção imaginativa e a imaginação perceptiva, indo além do referido pacto, Estômago produz um discurso identitário e crítico, que poderá vir a marcar a filmografia brasileira, ressignificando visões internas e externas sobre quem somos.

\section{Referências bibliográficas}

BHABHA, Homi. O local da cultura. Belo Horizonte: Ed. da UFMG, 1998.

BATAILLE, Georges. O Erotismo. Lisboa: Edições Antígona, 1988.

BENTES, Ivana. "Estéticas da Violência no Cinema”. Interseções: Revista de Estudos interdisciplinares. Ano 5, nº 1. Rio de Janeiro: PPGCOM/UERJ, 2003. pp. 217-237.

BERGSON, Henri. Oeuvres. Paris: PUF, 1963.

BORDWELL, David. Narration on the fiction film. Madison: Wisconsin: UWP, 1985.

CANCLINI, Néstor García. Consumidores e cidadãos: conflitos multiculturais da globalização. Rio de Janeiro: Ed. UFRJ, 1995.

MARCUSE, Herbert. Eros e Civilização. São Paulo: Zahar Editores,1982.

MATURANA, Humberto; VARELA, Francisco. L'Arbre de la connaissance; racines biologiques de la compréhension humain. Paris: Addison-Wesley, 1994.

NAGIB, Lúcia. O Cinema da Retomada: depoimentos de 90 cineastas dos anos 90. São Paulo, Ed. 34, 2002.

RAMOS, Fernão. (org.) História do cinema brasileiro. São Paulo: Art Editora, 1987. 
ROISSINI, Miriam de Souza.”O corpo da nação: imagens e imaginários no cinema brasileiro”. Revista FAMECOS. nº 34. Porto Alegre, dez. 2007. pp. 22-28

XAVIER, Ismail. O discurso cinematográfico: a opacidade e a transparência. Rio de Janeiro: Paz e Terra, 1984.

Referências na Internet

Entrevista com Marcos Jorge em Berlim, por Soraia Vilela. Disponível em www.dwworld.de/dw/article/ (Acesso 12 de nov.2008)

Site oficial do filme. www.portaldecinema.com.br/filmes/estomago (Acesso 10 de nov. 2008)

Filmografia

Estômago

Ano: 2007

Brasil / Itália

Direção: Marcos Jorge

Roteiro: Lusa Silvestre, Marcos Jorge, Cláudia da Natividade e Fabrizio Donvito, baseado em argumento de Lusa Silvestre e Marcos Jorge

- Elenco: João Miguel (Raimundo Nonato), Fabiula Nascimento (Iria), Babu Santana (Bujiú),Carlo Briani (Giovanni), Zeca Cenovicz (Zulmiro), Paulo Miklos (Etecetera), Jean-Pierre Noher (Duque), etc.. 